\title{
Mortality Rate In Intensive Care Units of Tertiary Health Institutions and Identifying Risk Factors: Analysis of 3945 Patients
}

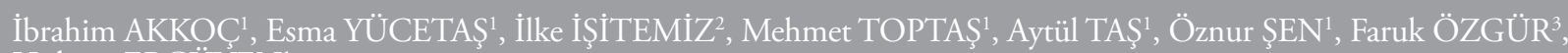
Hidayet ERGÜVEN ${ }^{1}$

${ }^{1}$ Clinic of Anesthesia and Reanimation, Haseki Training and Research Hospital, İstanbul, Turkey

${ }^{2}$ Clinic of Anesthesia and Reanimation, Antakya State Hospital, Hatay, Turkey

${ }^{3}$ Medical Biochemistry Laboratory, Haseki Training and Research Hospital, İstanbul, Turkey

\section{ABSTRACT}

Objective: To evaluate demographic data of patients hospitalized in the intensive care unit (ICU) of a tertiary health institution and to reveal demographic and laboratory parameters associated with mortality.

Methods: Between January 2008 and 2013, patients who were hospitalized in our clinic were retrospectively analyzed. During the evaluation, the demographic characteristics of patients; creatinine, urea, uric acid, albumin, LDH, ALT, AST, sodium, and hemoglobin levels; hematocrit; and white blood cell and platelet counts were assessed. The patients were then divided into two groups according to those who died and those transferred to a service.

Results: Between January 2008 and 2013, a total of 3945 patients were enrolled. In patients who died in the ICU, the average age, presence of an operation history, and hospitalization time in the ICU were statistically significant. After the evaluation, laboratory parameters including urea, creatinine, uric acid, and LDH levels and white blood cell count were significantly higher in patients who died in the ICU than in those who were transferred to a relevant service as healthy patients. Further, serum albumin, and hemoglobin levels; hematocrit; and platelet count were significantly lower in patients who died.

Conclusion: In elderly patients, the presence of am operation history and elevated urea, creatinine, uric acid, and LDH levels and white blood cell counts and decreased albumin and hemoglobin levels; platelet counts; and hematocrit were significantly associated with higher mortality rates in the ICU.

Keywords: Creatinine, Intensive Care Unit, thrombocytopenia, mortality, demographics

\section{Introduction}

Intensive care units (ICU) are special units in which patients with life-threatening health problems are followed and treated, and support units are used when necessary for the maintenance of life functions (1). The need for an ICU increases as the population rises worldwide and the number of elderly people having comorbidities increases. Since the treatment is expensive and the number of beds is limited, the patients who may benefit from the intensive care hospitalization should be chosen cautiously. Moreover, determining the factors that increase the rate of mortality in patients hospitalized in the ICU will decrease mortality.

When the studies in literature are considered, mortality rates of patients in the ICU vary between $20.5 \%$ and $43 \%$, and the most common causes of death are sepsis, cardiopulmonary arrest, pneumonia, and arrhythmias (2). Moreover, as ICU patients are generally old and have weakened immune system, their mortality rates increase. Additionally, performing invasive procedures frequently for patients in ICU, close contact of patients with the health staff, unnatural nutrition of patients, and abnormalities of their blood parameters attract attention as the most important factors that increase mortality (3).

Cite this article as: Akkoç I, Yücetaş E, Iş̧itemiz İ, Toptaş M, Taş A, Şen Ö, et al. Mortality Rate In Intensive Care Units of Tertiary Health Institutions and Identifying Risk Factors: Analysis of 3945 Patients. Bezmialem Science 2017; 5: 116-20.

$\begin{array}{lll}\text { Address for Correspondence: Ibrahim AKKOÇ; Haseki Eğitim ve Araştırma Hastanesi, Anestezi ve Reanimasyon Kliniği, } & \text { Received } & : 21.06 .2016 \\ \text { İstanbul, Türkiye E-mail: ibrakkoc@gmail.com } & \text { Accepted } & : 18.07 .2016 \\ \text { oCopyright } 2017 \text { by Bezmialem Vakif University - Available online at www.bezmialemscience.org } & \end{array}$


In this study, we aimed to investigate the clinical characteristics of the patients treated in intensive care unit in our hospital, the mortality effects of the patients' intensive care unit parameters and the mortality rates in patients.

\section{Methods}

After obtaining local ethical committee approval, the files of patients who were hospitalized in the ICU of our hospital between January 2008 and January 2013 were searched retrospectively. Only the patients who were treated in the ICU of our hospital and discharged or were exitus were included in the study. Patients who were sent to other centers during their treatment and those who were sent to our hospital to continue their treatment were excluded from the study. Also, the patients whose files could not be accessed were excluded from the study.

While the files of the patients were examined, the clinical parameters of patient demographic characteristics, primary intensive care hospitalization diagnosis group, indication for intensive care hospitalization, comorbid diseases, need for mechanical ventilation and duration, re-intubation, ICU hospitalization duration, and ICU mortality were evaluated over the data processing system of the hospital. Moreover, patients' laboratory values of creatinine, urea, uric acid, albumin, lactate dehydrogenase (LDH), aspartate transaminase (AST), alanine transaminase (ALT), sodium, hematocrit, hemoglobin, white blood cell count, and thrombocyte count at the time of their hospitalization were examined. The patients were divided into two groups as those who were referred to the related service in a healthy state from ICU and those who were exitus. These two groups were compared in terms of demographic data and laboratory parameters.

\section{Statistical Analysis}

Descriptive statistics were expressed according to the data type as mean, standard deviation (SD), median (interquartile range), and percentage. The factors affecting ICU hospitalization duration and mortality were tested using regression analysis. Mann-Whitney U, Chi square, t- tests were used according to the data type for comparison between the groups. The Statistical Package for Social Sciences 18.0 version (SPSS Inc; Chicago, IL, US) program was used for statistical analysis and a $p$ value of $<0.05$ was accepted as statistically significant.

\section{Results}

After excluding the patients not conforming with the study criteria, a total of 3945 patients, 2194 males and $1751 \mathrm{fe-}$ males, receiving treatment in our hospital ICU between January 2008 and January 2013 were included. The mean age of the patients was 61.6 years. Of these patients, 1905 (48.4\%) were transferred to the ICU after surgery. Hemodynamic stability, respiratory failure, and change in mental state were detected as the most common hospitalization indications. Of the patients hospitalized in the ICU, $19.5 \%$ had a disease relating to more than one system, followed by nervous system diseases, cerebrovascular accidents, gastrointestinal disorders, and respiratory system diseases. The mean hospitalization durations in the ICU were $10.2 \pm 25.2$ days (range, $0-418$ days). The mortality rate was $32.5 \%$ (Table 1 ).

The mean age of patients who were exitus in the follow-up showed a high statistical significance compared to those who had recovered and were discharged $(\mathrm{p}<0,001)$. Moreover, both the groups displayed no difference in terms of gender. Also, the rate of undergoing an operation and duration of hospitalization in the ICU were significantly higher in the exitus patients. Similarly, the incidence of a disease related to more than one system was higher in the exitus patients $(\mathrm{p}<0.001 ;$ Table 2$)$.

When laboratory parameters were evaluated, the mean urea, creatinine, uric acid, $\mathrm{LDH}$, and white blood cell values of the

Table 1. Demographic characteristics of the patients hospitalized in the ICU

\begin{tabular}{|c|c|c|}
\hline \multicolumn{2}{|c|}{ Demographic data } & Number (n, \%) \\
\hline \multicolumn{2}{|l|}{ Age, years } & $61.6 \pm 18.9(1-10)$ \\
\hline \multirow[t]{2}{*}{ Gender } & Male & $2194(55.6)$ \\
\hline & Female & $1751(44.4)$ \\
\hline \multirow[t]{2}{*}{ Unit } & $\begin{array}{l}\text { Emergency intensive care } \\
\text { and reanimation }\end{array}$ & $1494(39.7)$ \\
\hline & $\begin{array}{l}\text { H. Intensive Care and } \\
\text { Reanimation }\end{array}$ & $2451(62.1)$ \\
\hline \multirow[t]{2}{*}{ Operation } & None & $2029(51.6)$ \\
\hline & Yes & $1905(48.4)$ \\
\hline \multicolumn{2}{|c|}{ Duration of hospitalization } & $10.2 \pm 25.2(0-418)$ \\
\hline \multirow[t]{2}{*}{ Result } & Recovery & $2662(67.5)$ \\
\hline & Exitus & $1283(32.5)$ \\
\hline \multicolumn{2}{|c|}{$\begin{array}{l}\text { Comorbid diseases (such as DM+HT, etc. } \\
\text { and vasculitis included) }\end{array}$} & $768(\% 19.5)$ \\
\hline \multicolumn{2}{|c|}{$\begin{array}{l}\text { Nervous system and } \\
\text { cerebrovascular diseases }\end{array}$} & $663(\% 16.9)$ \\
\hline \multicolumn{2}{|c|}{ Gastrointestinal system } & $512(\% 13)$ \\
\hline \multicolumn{2}{|c|}{ Respiratory system } & 373 (\%9.5) \\
\hline \multicolumn{2}{|c|}{ Cardiovascular system } & $356(\% 9.1)$ \\
\hline \multicolumn{2}{|c|}{ Urogenital system } & $340(\% 8.6)$ \\
\hline \multicolumn{2}{|c|}{$\begin{array}{l}\text { Musculoskeletal disorders } \\
\text { (orthopedical post-ops, etc.) }\end{array}$} & $268(\% 6.8)$ \\
\hline \multicolumn{2}{|c|}{ Hepatobiliary system } & $145(\% 3.7)$ \\
\hline \multicolumn{2}{|c|}{ Endocrine and metabolic system } & $145(\% 3.7)$ \\
\hline \multicolumn{2}{|c|}{ hematopoietic system } & $89(\% 2.3)$ \\
\hline \multicolumn{2}{|c|}{ Infection diseases } & $82(\% 2.1)$ \\
\hline \multicolumn{2}{|c|}{$\begin{array}{l}\text { Others (traumas, traffic accidents, } \\
\text { intoxication, firearm, drowning in water, } \\
\text { and genetic diseases) }\end{array}$} & $192(\% 4.9)$ \\
\hline \multicolumn{3}{|c|}{ ICU: intensive care unit, n: number, H: Haseki Training and Research } \\
\hline
\end{tabular}




\begin{tabular}{|c|c|c|c|c|}
\hline & & Exitus (n, \%) & Recovered (n, \%) & $\mathbf{p}$ \\
\hline \multicolumn{2}{|l|}{ Age. years } & $63.8 \pm 18.4(1-101)$ & $60.5 \pm 19.0(1-99)$ & $<0.001$ \\
\hline \multirow[t]{2}{*}{ Gender } & Male & $735(57.3)$ & $1459(54.8)$ & 0.142 \\
\hline & Female & $548(42.7)$ & $1203(45.2)$ & \\
\hline \multirow[t]{2}{*}{ Unit } & Emergency intensive care and reanimation & $566(44.1)$ & $928(34.9)$ & $<0.001$ \\
\hline & H. Intensive Care and Reanimation & $717(55.9)$ & $1734(65.1)$ & \\
\hline \multirow[t]{2}{*}{ Operation } & None & $992(77.4)$ & $1037(39.1)$ & $<0.001$ \\
\hline & Yes & $289(22.6)$ & $1616(60.9)$ & \\
\hline \multicolumn{2}{|c|}{ Duration of hospitalization } & $17.7 \pm 33.4$ & $6.6 \pm 19.1$ & $<0.001$ \\
\hline \multicolumn{2}{|c|}{ Comorbid diseases } & $372(\% 29.1)$ & $396(\% 14.9)$ & $<0.001$ \\
\hline \multicolumn{2}{|c|}{ Nervous system and cerebrovascular diseases } & $230(\% 18.0)$ & $433(\% 16.3)$ & \\
\hline \multicolumn{2}{|c|}{ Gastrointestinal system } & $116(\% 9.1)$ & $396(\% 14.9)$ & \\
\hline \multicolumn{2}{|c|}{ Respiratory system } & $95(\% 7.4)$ & $278(\% 10.5)$ & \\
\hline \multicolumn{2}{|c|}{ Cardiovascular system } & $174(\% 13.6)$ & $182(\% 6.9)$ & \\
\hline \multicolumn{2}{|c|}{ Urogenital system } & $54(\% 4.2)$ & $286(\% 10.8)$ & \\
\hline \multicolumn{2}{|c|}{ Musculoskeletal disorders } & $25(\% 2.0)$ & $243(\% 9.2)$ & \\
\hline \multicolumn{2}{|c|}{ Hepatobiliary system } & $34(\% 2.7)$ & $111(\% 4.2)$ & \\
\hline \multicolumn{2}{|c|}{ Endocrine-metabolic system } & $31(\% 2.4)$ & $114(\% 4.3)$ & \\
\hline \multicolumn{2}{|c|}{ Hematopoietic system } & $45(\% 3.5)$ & $44(\% 1.7)$ & \\
\hline \multicolumn{2}{|c|}{ Infection diseases } & $43(\% 3.4)$ & $39(\% 1.5)$ & \\
\hline \multicolumn{2}{|l|}{ Others } & $60(\% 4.7)$ & $132(5)$ & \\
\hline
\end{tabular}

Table 3. Comparison of demographic characteristics of the patients who were exitus and discharged patients to their services

\begin{tabular}{l|c|c|c|} 
Serum parameters & Exitus & Recovered & P \\
\hline Urea & $82.5 \pm 66.8$ & $55.1 \pm 48.0$ & $<0.001$ \\
Creatinine & $2.2 \pm 2.4$ & $1.4 \pm 1.6$ & $<0.001$ \\
Uric acid & $6.0 \pm 3.1$ & $4.2 \pm 2.5$ & 0.018 \\
Albumin & $2.6 \pm 0.7$ & $2.8 \pm 0.7$ & $<0.001$ \\
LDH & $574.3 \pm 1297.8$ & $467 \pm 811.3$ & 0.011 \\
AST & $167.8 \pm 593.9$ & $149.0 \pm 586.0$ & 0.195 \\
ALT & $125.7 \pm 342.6$ & $108.4 \pm 333.7$ & 0.111 \\
Sodium & $138.5 \pm 7.9$ & $137.9 \pm 5.2$ & 0.253 \\
Hematocrit & $32.9 \pm 7.6$ & $33.7 \pm 6.8$ & $<0.001$ \\
Hemoglobin & $10.8 \pm 2.5$ & $11.1 \pm 2.3$ & $<0.001$ \\
\hline Thrombocyte & $228.9 \pm 131.5$ & $244.4 \pm 130.0$ & $<0.001$ \\
White blood cell & $14.3 \pm 10.8$ & $13.1 \pm 7.2$ & 0.021 \\
\hline LDH; lactate dehydrogenase, AST; aspartate transaminase, ALT; alanine \\
\hline transaminase & & &
\end{tabular}

exitus patients were statistically higher than those of patients over, the mean serum albumin, hematocrit, hemoglobin, and thrombocyte values in the exitus patients' group were significantly low $(\mathrm{p}<0.001)$. Both groups displayed no significant difference in terms of sodium, AST, and ALT (Table 3).

\section{Discussion}

It is known that ICUs are departments in which mortality rates are the highest (2-4). Knowing the factors that affect mortality is quite important for the physicians working at the ICU in comprehending the severity of the disease and taking necessary precautions. Recently, for the evaluation of patients hospitalized in the ICU, scoring systems, such as Acute Physiology and Chronic Health Evaluation (APACHE), Mortality Prediction Model (MPM), Multiple Organ Dysfunction Score (MODS), and Sequential Organ Failure Assessment Score (SOFA) are used. The scores using physiologic measurements display parallelism with prognosis and the mortality risk of the disease (5). We also examined the demographic data and laboratory parameters of the patients, which may affect the mortality in ICU.

The total mortality rate of the patients followed up in the ICU was $32.5 \%$ and this rate was similar with other studies in literature $(2,3)$. When the units where the patients were 
hospitalized were evaluated, it was detected that the mortality rate in the emergency ICU was significantly higher than that in the general ICU $(p<0,001)$. The frequency of an operation was higher in the medical histories of exitus patients compared to those discharged with complete recovery $(\mathrm{p}<0.001)$. We attribute this result to the fact that the ICU need of patients hospitalized in general clinics can be predicted and these patients can be transferred to the ICU after a faster intervention.

The age of the patient is considered a factor affecting mortality rates in ICU, similar to other studies. In the study conducted by Furchs et al., it was suggested that the mortality increased over the age of 75 years and that age was an independent risk factor in determining mortality $(7,8)$. In our study, the mean age of patients who were exitus was statistically higher than that of patients who were discharged from the hospital with complete recovery $(\mathrm{p}<0.001)$.

The hospitalization duration in ICUs is relatively important since the bed availability of ICUs is limited. In the study conducted by Sticker et al. (9), it was reported that only $11 \%$ of the patients stayed more than 1 week in the ICU. Furthermore, Fakhry suggested that functional recoveries of the patients staying more than 2 weeks in the ICU were less than $50 \%$ and less than one-half of these patients could return to their normal lives (10). Additionally, some studies have shown that the patient mortality can reach up to $50 \%$ in hospitalizations longer than 2 weeks in the ICU (11). In this study, while the duration of hospitalization of the patients who were exitus was $17.7 \pm 33.4$, it was detected as $6.6 \pm 19.1$ in those who were discharged with complete recovery, with a statistically significant difference $(\mathrm{p}<0,001)$.

In our study, low levels of albumin, hematocrit, hemoglobin, and thrombocytes were more common in the exitus group. A higher frequency of comorbid diseases in this patient group may be one of the reasons explaining this situation. Liver diseases and kidney diseases leading to protein leakage may cause hypoalbuminemia. Moreover, systemic diseases impair blood cell formation by suppressing bone marrow with the stress they create (12). Additionally, multiple drug use by patients having many comorbid diseases can suppress bone marrow (13).

Previous or newly occurring renal damage in the patients admitted to the ICU affect the mortality rates of patients. Fluid loss appearing in these patients, hypotension, sepsis, and rhabdomyolysis cause renal damage. Moreover, acute renal damage or deterioration of renal functions of the patients also increases mortality (14). In our study, the laboratory parameters, such as urea, creatinine, and uric acid, were significantly high in the ICU exitus patients $(\mathrm{p}<0,001)$.

There are important deficiencies of our study although it was conducted in a tertiary health care center with a high patient load. Retrospective design of the patient is one of them. Lack of scoring system usage during the evaluation of patients is one of the limitations of the study. At the same time, grouping the comorbid diseases only under the name of systemic diseases and not using scoring systems for indicating their severity can be accepted as weaknesses of the study.

Our study has shown that age, surgical history, and multiplesystem comorbid disease increase the mortality rate. Moreover, urea, creatinine, uric acid, and elevated white blood cell count as laboratory parameters along with albumin, hematocrit, and low level of thrombocyte are linked with mortality significantly.

Ethics Committee Approval: Ethics committee approval was received for this study from the ethics committee of Haseki Training and Research Hospital.

Informed Consent: Written informed consent was not obtained from patients due to the retrospective design of study.

Peer-review: Externally peer-reviewed.

Author Contributions: Concept - İ.A.; Design - M.T., F.Ö.; Supervision - Ö.Ş.; Resources - M.T., İ.A., F.Ö.; Materials - H.N.E, Ö.Ş.; Data Collection and/or Processing - M.T., F.Ö.; Analysis and/ or Interpretation - İ.A., E.Y.; Literature Search - M.T., F.Ö.; Writing Manuscript - M.T., F.Ö.; Critical Review - M.T., F.Ö.; Other - H.N.E., Ö.Ş., İ.İ., A.T.

Conflict of Interest: No conflict of interest was declared by the authors.

Financial Disclosure: The authors declared that this study has received no financial support.

\section{References}

1. Walter KL, Siegler M, Hall JB. How decisions are made to admit patientst medica lintensive care units: A survey of MICU directors at academic medical centers across the United States. Crit Care Med 2008; 36: 414-20. [CrossRef]

2. Ceylan E, İtil O, Arı G et al. İç hastalıkları yoğun bakım ünitesinde izlenmiş hastalarda mortalite ve morbiditeyi etkileyen faktörler. Toraks Dergisi 2001; 2: 6-12.

3. Gürkan ÖU, Berk Ö, Kaya A et al. Evaluation of a respiratory intermediate care unit in Ankara: Two year analysis. Turkish Respiratory Journal 2001; 2: 20-5.

4. Uçgun İ, Metintaş $M$, Moral $M$ et al. Malign patolojisi olmayan solunum yoğun bakım hastalarında mortalite hızı ve yüksek riskli hastaların belirlenmesi. Toraks Dergisi 2003; 4: 151-60.

5. Uysal N, Gündoğdu N, Börekçi Ş et al., Üçüncü Basamak Merkezde Dahili Yoğun Bakım Hastalarının Prognozu. Yoğun Bakım Derg 2010; 1: 1-5.

6. Fuchs L, Chronaki CE, Park S, et al. ICU admission characteristics and mortality rates among elderly and very elderly patients. Intensive Care Med 2012; 38:1654-61. [CrossRef]

7. Knaus WA, Draper EA, Wagner DP. APACHE II: A severity of disease classification system. Crit Care Med 1985; 13: 818-29. [CrossRef]

8. Sacanella E, Perez-Castejon JM, Nicolas JM, et al. Mortality in healthy elderly patients after ICU admission. Intensive Care Med 2009; 35: 550-5. [CrossRef] 
9. Stricker K, Rothen HU, Takala J. Resource use in the ICU: short- vs long-term patients. Acta Anaesthesiol Scand 2003; 47: 508-515. [CrossRef]

10. Fakhry SM, Kercher KW, Rutledge R. Survival, quality of life, and changes in critically ill surgical patients requiring prolonged ICU stays. J Trauma 1996; 41: 999-1007. [CrossRef]

11. Ryan TA, Rady MY, Bashour CA, Leventhal M, Lytle B, Starr NJ. Predictors of outcome in cardiac surgical patients with prolonged intensive care stay. Chest 1997; 112: 1035-1042. [CrossRef]
12. Nathanson BH, Higgins TL, Brennan MJ, et al. Do elderly patients fare well in the ICU? Chest 2011; 139: 825-31. [CrossRef]

13. Andersen FH, Kvåle R. Do elderly intensive care unit patients receiveless intensive care treatment and have higher mortality? Acta Anaesthesiol Scand 2012; 56:1298-305. [CrossRef]

14. Akın S, Gündoğan K, Coşkun R, et al. Yoğun Bakımda Yaşlı Hasta Mortalitesi: Yaş Risk Faktörü Mü? Yoğun Bakım Derg 2014; 5: 26-9 [CrossRef] 